\title{
COMPARISON BETWEEN QUALITATIVE AND SEMIQUANTITATIVE CATHETER-TIP CULTURES: LABORATORY DIAGNOSIS OF CATHETER-RELATED INFECTION IN NEWBORNS
}

\author{
Camila Marconi ${ }^{1}$; Maria de Lourdes RS Cunha ${ }^{2 *}$; João C Lyra ${ }^{3}$; Maria R Bentlin ${ }^{3}$; Jackson EN Batalha ${ }^{1}$; \\ Maria Fátima Sugizaki²; Lígia MSS Rugolo ${ }^{3}$
}

\begin{abstract}
${ }^{1}$ Departamento de Patologia, Faculdade de Medicina de Botucatu, Universidade Estadual Paulista, Botucatu, SP, Brasil; ${ }^{2}$ Departamento de Microbiologia e Imunologia, Instituto de Biociências de Botucatu, Universidade Estadual Paulista, Botucatu, SP, Brasil; ${ }^{3}$ Departamento de Pediatria, Faculdade de Medicina de Botucatu, Universidade Estadual Paulista, Botucatu, SP, Brasil
\end{abstract}

Submitted: September 27, 2007; Returned to authors for corrections: December 20, 2007; Approved: May 04, 2008.

\begin{abstract}
This prospective study evaluated semiquantitative and qualitative catheter-culture methods for diagnosis of catheter-related infection (CRI) in newborns. Catheter tips from newborns admitted to the Neonatal Unit of the University Hospital of the Botucatu Medical School, UNESP were included in the study. Catheter cultures were performed with both semiquantitative and qualitative techniques. For CRI diagnosis, microorganisms isolated from catheter cultures and from peripheral blood cultures were identified and submitted to agent susceptibility test. The gold standard was the certain CRI diagnosis when same microorganism (specie and profile of susceptibility to agents) was isolated from both catheter tips and peripheral blood culture. A total of 85 catheters from 63 newborns were included in the study. The semiquantitative culture method, despite presenting lower sensitivity (90\%), showed higher specificity (71\%) when compared to $100 \%$ of sensitivity and $60 \%$ of specificity in the qualitative method. The identification of the microorganisms obtained from the catheter cultures showed a prevalence of coagulase-negative staphylococci (CNS) species. The specie Staphylococcus epidermidis (77.5\%) was the prevalent in the catheters with positive semiquantitative cultures. Among 11 episodes with CRI diagnosis, 8 (72.7\%) were associated with CNS species, of which 6 were $S$. epidermidis. Two episodes of CRI by $S$. aureus and one by Candida parapsilosis were also detected. The semiquantitative catheter-culture method showed advantages for CRI diagnosis in newborns when compared to the conservative qualitative method.
\end{abstract}

Key-words: Catheter-related infection, catheter culture, semiquantitative culture, newborns, coagulase-negative staphylococci.

\section{INTRODUCTION}

The medical advances achieved in neonatal intensive care units (Neonatal ICU) in the last few decades have enabled a significant increase in preterm newborns' survival rates, particularly in those with low birth weight $(17,19)$. Numerous resources have been routinely used in these units, such as mechanical ventilation, parenteral nutrition and the insertion of umbilical catheters as well as the extensive use of antibiotics and long periods in neonatal ICU. These factors, despite contributing to lives of newborns (NB) preservation, act as predisposing factors to the development of nosocomial neonatal infections $(14,19,25,32,34,35)$.

Among all the used resources, intravascular catheters are distinguished. They are frequently used in numerous procedures in neonatal ICU, since they allow rapid intravenous access for the medication administration, parenteral nutrition and others (31). Although the use of catheters is a fundamental

*Corresponding Author. Mailing address: Departamento de Microbiologia e Imunologia, Instituto de Biociências - UNESP. Caixa Postal 510, Rubião Júnior, 18618-000 - Botucatu - SP. Fax + 5514 3815-3744, Phone +55 14 3811-6058. E-mail: cunhamlr@ibb.unesp.br 
procedure for NB's survival in neonatal ICU, it is also considered an important risk factor for infection acquisition. Additionally, it contributes to increase the incidence of bloodstream infections and, therefore, increases morbidity rates and hospitalization periods (3).

Similarly to what occurs in adults, nearly $60 \%$ of the catheterrelated bloodstream infections in NB are caused by gram-positive bacteria, among which coagulase-negative staphylococci (CNS) species are distinguished as they are associated with $37.7 \%$ of such infections (5). There are some important catheter contamination sources, however the most frequent is the NB's flora on the catheter insertion site (31). This explains why CNS are the most frequent microorganisms associated with such infections. Since they are the major component of NB skin and mucosal flora, they are recognized as the most frequent etiologic agents in NB infections, mainly in those with low birth weight $(<1,500 \mathrm{~g})(9,16,20)$.

Catheter-related infections (CRI) are diagnosed when identical microorganisms are isolated from catheter and blood cultures in absence of other apparent source of infection, except the catheter (4). The culture's reliability depends on the adopted technique. The major catheter-culture methods utilized for CRI diagnosis are the qualitative and semiquantitative methods. The qualitative or conservative broth method is the simplest and the most commonly used. However, the semiquantitative method proposed by Maki et al. (24) is recommended for CRI diagnosis by the Centers for Disease Control and Prevention (4). According to Maki's proposal, semiquantitative cathetertip culture is considered positive in the presence of 15 or more Colony-Forming Units (CFU) growth. Hence, this study aimed to compare two methods for CRI diagnosis in NB.

\section{MATERIALAND METHODS}

\section{Sampling}

Eighty-five catheter tips from 63 newborns admitted to the Neonatal Unit of the University Hospital of the Botucatu Medical School, UNESP, between September 2001 and June 2003, were included in this prospective study.

Catheter tips from patients who had presented one or more blood cultures collected close to the date of catheter removal were included. Catheters from NB whose clinical data and laboratory records referring to a one-week period prior to the device's removal date were not available were excluded of the study. The procedures were approved by Medical School Research Ethics Committee.

\section{Catheter culture}

The catheter-tip cultures were performed by Maki's semiquantitative method (24). The catheters were aseptically removed by the medical staff and the approximately $5 \mathrm{~cm}$ distal tips were collected, placed in dry sterile vials and immediately transported to the laboratory for processing. The segments were rolled on the surface of Blood Agar plates and incubated at $37^{\circ} \mathrm{C}$ for 72 hours. The plates were examined daily and counted as soon as growth was detected, the result was expressed in CFU. The catheter tips were also cultured with Qualitative or Conservative method that consisted in immersing the catheter tips in Brain Heart Infusion (BHI) with subsequent incubation at $37^{\circ} \mathrm{C}$ for 72 hours. The broths were examined daily and when cloudy, a subculture was performed in Blood Agar.

\section{Blood culture}

The blood cultures were collected and cultivated by the Bactec Automated System, according to Koneman et al. guidelines (23).

\section{Microorganism identification}

The microorganisms were submitted to Gram staining for purity assessment and morphology and specific stain examination. After confirmation of these characteristics, identification tests were performed as recommended by Koneman et al. (23).

\section{Identification of coagulase-negative Staphylococci}

Identification was performed according Kloos and Bannerman (21), Kloos and Schleifer (22) and Cunha et al. (10) with a simplified scheme of biochemical tests which includes the performance of catalase and coagulase tests, as well as of sugar utilization tests: xylose, arabinose, saccharose, trehalose, mannitol, maltose, lactose, xylitol, ribose and fructose, in addition to the characterization of hemolysins, nitrate reduction, urease production, ornithine descarboxylase and Novobiocin resistance $(5 \mu \mathrm{g})$.

\section{Susceptibility test}

The susceptibility test was performed using the technique of agent diffusion from impregnated discs on agar, according National Committee for Clinical Laboratory Standards-NCCLS guidelines (27). For inoculum preparing, BHI cultures of the microorganisms obtained from catheter tips and blood cultures were previously incubated for 4 to 6 hours and adjusted to 0,5 McFarland density scale before plating. The following discs were utilized: Penicillin G (10U), Oxacillin (1 $\mu \mathrm{g})$, Tetracycline (30 $\mu \mathrm{g})$, Chloramphenicol $(30 \mu \mathrm{g})$, Erythromycin $(15 \mu \mathrm{g})$, Cephalothin $(30 \mu \mathrm{g})$, Netilmicin $(30 \mu \mathrm{g})$, Gentamicin $(30 \mu \mathrm{g})$, Novobiocin (5 $\mu \mathrm{g})$, Cefotaxime $(30 \mu \mathrm{g})$, Cefaclor $(30 \mu \mathrm{g})$, Levofloxacin $(5 \mu \mathrm{g})$, Ofloxacin $(5 \mu \mathrm{g})$, Rifampin $(5 \mu \mathrm{g})$, Vancomycin $(30 \mu \mathrm{g})$ and Teicoplanin $(30 \mu \mathrm{g})$. Following the incubation at $37^{\circ} \mathrm{C}$ for 24 hours, the halos were measured $(\mathrm{mm})$, and the results obtained were compared between the microorganisms isolated from the same NB (catheter and blood cultures) in order to observe the similarity between samples. 


\section{Catheter-related infection (CRI) diagnosis}

CRI was diagnosed according to CDC guidelines (4) by the presence of two or more of the following signs or symptoms: fever $\left(\geq 38^{\circ} \mathrm{C}\right)$, hypothermia $\left(<36^{\circ} \mathrm{C}\right)$, apnea, bradycardia or shock signs, in addition to the presence of one or more positive blood cultures in patients whose catheter semiquantitative culture was positive, if the same microorganism (specie and agent susceptibility) had been isolated from the catheter and the peripheral blood culture without another apparent source of infection focus except the catheter.

\section{Statistics}

Culture accuracy was obtained by determination of sensitivity (S) and specificity (SP), and CRI was calculated from the positive predictive value (PPV) and the negative predictive value (NPV).

\section{RESULTS}

Eighty-five catheters from $63 \mathrm{NB}$ admitted to the Neonatal Unit of the University Hospital of the Botucatu Medical School, UNESP were studied. The mean time of catheter use was 10 days, ranging from 1 to 33 days. Among the catheters, $36.6 \%$ were the umbilical vascular type, $34.1 \%$ umbilical arterial, $17,1 \%$ central vascular and $12.2 \%$ peripheral.

Of all the catheters included in the study, $54(63.5 \%)$ had negative cultures by Maki's semiquantitative method, of which 13 (15.3\%) showed growth with less than $15 \mathrm{CFU}$, whereas the remaining 41 (48.2\%) catheters did not present growth of any colony. The semiquantitative culture was positive, by showing growth equal or superior to $15 \mathrm{CFU}$, in 31 (36.5\%) catheter tips (Table 1).

In relation to the qualitative method, it was observed that 45 (52.9\%) catheter tips had negative cultures, whereas the remaining $40(47.1 \%)$ had positive culture by this method, by presenting culture medium clouding (Table 1).

The catheter-related infection diagnosis was observed in 11 episodes. In six (54.5\%) of them, it was observed a confluent

Table 1. Results from the catheter cultures by the semiquantitative and qualitative methods.

\begin{tabular}{cccccc}
\hline & \multicolumn{4}{c}{ Catheter culture } \\
\cline { 2 - 6 } Catheter & \multicolumn{2}{c}{ Semiquantitative } & \multicolumn{2}{c}{ Qualitative } \\
\cline { 2 - 6 } & No & $<15$ & $\geq 15$ & Negative & Positive \\
& growth & CFU & CFU & & \\
\hline $\mathrm{N}$ & 41 & 13 & 31 & 45 & 40 \\
$\%$ & 48.2 & 15.3 & 36.5 & 52.9 & 47.1 \\
\hline
\end{tabular}

$\mathrm{N}=$ Total number of catheters. $\mathrm{CFU}=$ Colony-Forming Units. growth on Blood Agar plates (Fig. 1); other 4 (36.4\%) CRI episodes presented culture growth $\geq 100 \mathrm{CFU}$, and, in the remaining episode it was verified an $8 \mathrm{CFU}$ growth. Besides this last episode did not present a culture growth superior to 15 CFU, it consisted in a certain CRI diagnosis since it presented infection by the same specie, Staphylococcus aureus, with similar agent susceptibility in both catheter and blood culture in this patient.

The results regarding the identification of the microorganisms obtained from the catheter semiquantitative cultures revealed a predominance of CNS species (Table 2) either in cultures with growth $<15 \mathrm{CFU}(76.9 \%)$ or in those presenting

Table 2. Microorganisms isolated from catheter tips by the semiquantitative culture.

\begin{tabular}{lccc}
\hline Microorganisms no. (\%) & $<15$ CFU & $\geq 15$ CFU & CRI \\
\hline S. epidermidis & $9(69.2)$ & $24(77.5)$ & $6(54.5)$ \\
S. warneri & - & $1(3.2)$ & $1(9.1)$ \\
S. simulans & - & $1(3.2)$ & $1(9.1)$ \\
S. haemolyticus & $1(7.7)$ & - & - \\
\hline Total CNS & $10(76.9)$ & $26(83.9)$ & $8(72.7)$ \\
\hline S. aureus & $1(7.7)$ & $1(3.2)$ & $2(18.2)$ \\
Acinetobacter baumannii & & $1(3.2)$ & \\
Candida parapsilosis & $1(7.7)$ & $3(9.7)$ & $1(9.1)$ \\
Gram Positive Rods & $1(7.7)$ & & \\
\hline Total & 13 & 31 & 11 \\
\hline
\end{tabular}

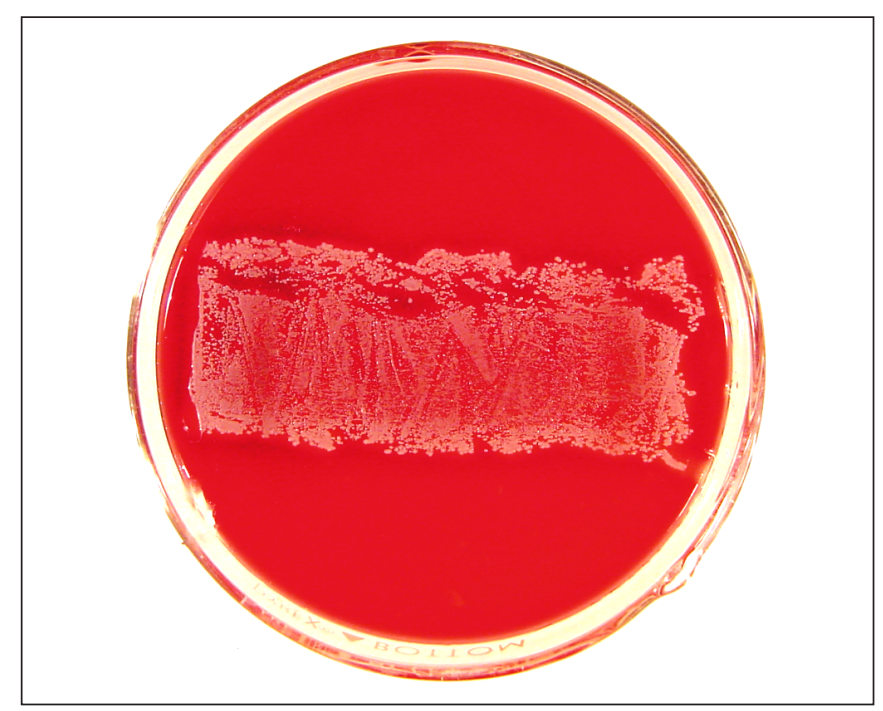

Figure 1. Catheter-tip semiquantitative culture with confluent growth. 


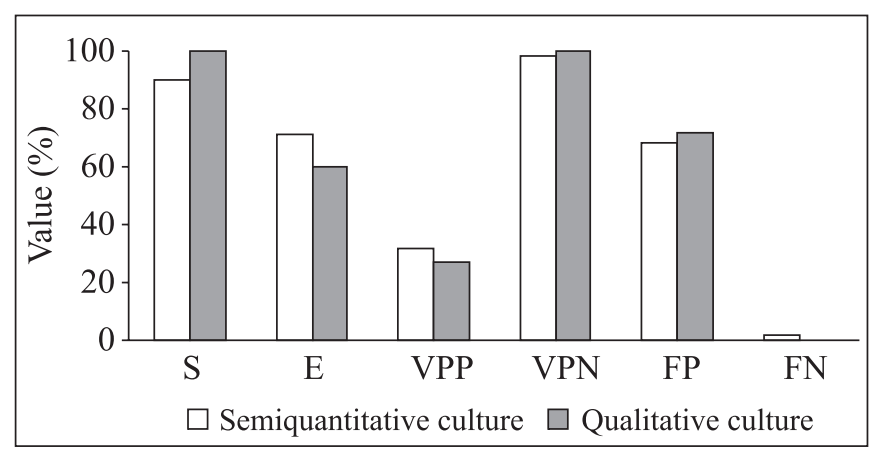

Figure 2. Sensitivity (S), specificity (SP), positive predictive (PPV), negative predictive (NPV), false-negative (FN) and falsepositive (FP) values for the semiquantitative and qualitative catheter-culture methods.

growth $\geq 15$ CFU (83.9\%). S. epidermidis was the prevalent specie $(77.5 \%)$ related to catheter colonization ( $\geq 15 \mathrm{CFU})$. Among the 11 CRI episodes, 8 (72.7\%) were associated with CNS species, of which 6 were $S$. epidermidis.

The comparison between the two techniques for CRI diagnosis (Fig. 2) showed 100\% sensitivity for the conservative broth culture or qualitative method. For this method, it was also find specificity and positive predictive value of, respectively, $60 \%$ and $27 \%$. Even though Maki's semiquantitative method presented lower sensitivity (90\%), the rates related to specificity (71\%) and positive predictive value (32\%) were higher when compared to the qualitative method.

\section{DISCUSSION}

The advances achieved in neonatology in the last few decades have enabled significant increase in the survival of preterm newborns as well as in that of newborns with low weight at birth; nevertheless, a progressive increase in the diagnosis of nosocomial infection in neonatal ICU (17) have also been verified as a result. The use of invasive procedures in such units is an important risk factor for the development of nosocomial infections (33), among which catheter-related infections (CRI) are distinguished (3). In this prospective study, 85 catheters from $63 \mathrm{NB}$ admitted to the ICU and submitted to peripheral, umbilical venous, umbilical arterial or central venous catheterization with a mean duration of 10 days were analyzed. Similarly to findings from studies in the literature $(7,26,32)$, no correlation between the catheterization type used and the presence or absence of CRI was found.

CRI is diagnosed when identical microorganisms are detected in both catheter and blood cultures (4), and the comparison of microorganisms through the susceptibility test, although less specific than genotyping methods, is considered to be efficient and relatively inexpensive (28).
In this study, all catheters from NB with confirmed CRI diagnosis presented positive culture by the conservative catheter-tip culture method, or qualitative method. In relation to Maki's semiquantitative culture method (24), it is considered one of the most frequently used techniques for CRI diagnosis by presenting a $\geq 15 \mathrm{CFU}$ growth, and various studies show its importance $(8,28)$. However, in this study, a catheter tip of a patient with diagnosed Staphylococcus aureus CRI presented negative semiquantitative culture, with a growth of only $8 \mathrm{CFU}$. Other authors also verified the association between CRI and semiquantitative cultures with growth inferior to $15 \mathrm{CFU}(8)$. These results can be explained by either use of antibiotics prior to the culture collection or intraluminal contamination of the catheter, which is a limiting factor to the semiquantitative culture, since it only detects the microorganisms adhered to the external surface of the device (18). On the other hand, some authors point out the contamination of the catheter's external surface as a predominant infection route in short-duration catheters ( $<30$ days), whereas intraluminal contamination is important in prolonged catheterization with a mean duration of 23.4 to 26.5 days $(1,18)$.

Coagulase-negative staphylococci (CNS), which are the major components of NB's skin and mucosa flora (11), are the etiologic agents most frequently involved with CRI in $\mathrm{NB}(5,20)$. In our study, the frequencies of microorganisms associated with CRI occurrence are in agreement with data in the literature, since CNS species were related to most of the cases observed $(72.7 \%)$. Also, these are microorganisms that are knowingly related to most CRI episodes in NB $(5,7,19)$. In this study, two cases of CRI by $S$. aureus and one case by Candida parapsilosis were also detected and both microorganisms are cited in the literature as frequent, although not prevalent, etiologic agents in CRI cases in NB (7,29). From 1991 to 1999, CNS were responsible for $37.7 \%$ of CRI in pediatric ICUs (5), which was followed by $S$. aureus (12.6\%), whereas Candida spp. represented $8 \%$ to $9 \%$ of the findings. Various preceding studies on adult patients also showed that the three major agents causing CRI are coagulase-negative staphylococci, $S$. aureus and Candida spp. $(2,12,15)$. The two former agents mainly originate from the skin during catheter insertion or from the health care staff's hands. Candida albicans, followed by $C$. parapsilosis are the main representatives of this gender in catheter-related infections $(6,13,15)$.

Among the $8 \mathrm{CRI}$ cases associated with CNS species, Staphylococcus epidermidis was present in $6(54.5 \%)$ cases. Such higher frequency of $S$. epidermidis in this disease is expected, since, according to D'Angio (11), this species is predominant in NB's flora around the fourth day of life. Such predominance in the colonization of individuals and the greater pathogenicity of some strains can explain the fact that $S$. epidermidis is the species most commonly associated with infectious processes in NB as reported in a study performed by 
Cunha et al. (9). CNS were also the prevalent organisms in catheter colonization, that is, catheters with growth $\geq 15 \mathrm{CFU}$.

The comparison between the qualitative and semiquantitative catheter-culture techniques showed agreement with data in the literature. In a metaanalysis by Safdar et al. (30), the sensitivity mean found for the qualitative culture was of $90 \%$, while specificity was $72 \%$. Nevertheless, although the semiquantitative culture showed lower sensitivity $(85 \%)$, it exhibited higher specificity (82\%). In this study, although the sensitivity found in the qualitative-culture method was $100 \%$ in contrast to $90 \%$ shown by the semiquantitative method, specificity was lower for the qualitative method, where $60 \%$ was found in contrast to $71 \%$. The semiquantitative culture also showed larger positive predictive value (PPV), in addition to being a more rapid technique, since it is capable of detecting positive results in up to 24 hours.

It was concluded that the semiquantitative culture is a rapid and efficient technique for diagnosing catheter-related infection in NB. However, it requires careful interpretation, and its result must be part of a set of factors that can indicate diagnosis and a specific treatment.

\section{RESUMO}

\section{Comparação entre culturas qualitativa e semiquantitativa de ponta de cateter: Diagnóstico laboratorial de infecção relacionada a cateter em recém-nascidos}

Este estudo prospectivo avaliou os métodos semiquantitativo e qualitativo de cultura de cateter para o diagnóstico de infecção relacionada a cateter (IRC) em recém-nascidos (RN). Foram incluídas pontas de cateteres provenientes de recém-nascidos internados na Unidade Neonatal do Hospital das Clínicas da Faculdade de Medicina de Botucatu, UNESP. Foram utilizadas as técnicas semiquantitativa e qualitativa de cultura de cateter. Para o diagnóstico de IRC, os microrganismos isolados das culturas de cateteres e de hemoculturas periféricas foram identificados e submetidos ao teste de sensibilidade a antimicrobianos. O padrão ouro correspondeu ao diagnóstico de certeza de IRC, com o isolamento do mesmo microrganismo (espécie e perfil de sensibilidade a antimicrobianos) isolado em hemocultura periférica. Foram estudados 85 cateteres provenientes de $63 \mathrm{RN}$. A cultura semiquantitativa, embora tenha apresentado menor sensibilidade (90\%), apresentou uma maior especificidade (71\%) em comparação à sensibilidade de $100 \% \mathrm{e}$ especificidade de $60 \%$ encontradas na cultura qualitativa. Através da identificação dos microrganismos obtidos nas culturas de cateteres, observou-se uma predominância de espécies de Estafilococos coagulase-negativa (ECN). A espécie Staphylococcus epidermidis foi a prevalente $(77,5 \%)$ nos cateteres com culturas semiquantitativas positivas. Dos 11 episódios de IRC diagnosticados, 8 (72,7\%) foram associados a espécies de ECN, dos quais 6 eram da espécie $S$. epidermidis. Também foram detectados dois casos de IRC por $S$. aureus e um caso por Candida parapsilosis. O método de cultura semiquantitativo cateter apresentou vantagens para o diagnóstico de IRC em RN quando comparado com o método qualitativo tradicional.

Palavras-chave: Infecção relacionada a cateter, cultura de cateter, cultura semiquantitativa, recém-nascidos, Estafilococos coagulase-negativa.

\section{REFERENCES}

1. Blot, F. (2002). New techniques for diagnosing catheter-related infection. Clin. Pulm. Med., 9 (3), 164-170.

2. Bouza, E.; Juan, R.S.; Muñoz, P.; Pascau, J.; Voss, A.; Desco, M.; Cooperative Group of the European Study Group on Nosocomial Infections (ESGNI). (2004). A European perspective on intravascular catheter-related infections: report on the microbiology workload, aetiology and antimicrobial susceptibility (ESGNI-005 Study). Clin. Microbiol. Infect. Dis., 10 (9), 838-842.

3. Carrieri, M.P.; Stolfi, I.; Moro, M.L.; Italian Study Group on Hospital Acquired Infections in Neonatal Intensive Care Units. (2003). Intercenter variability and time of onset: two crucial issues in the analysis of risk factors for nosocomial sepsis. Pediatr. Infect. Dis. J., 22 (7), 599-609.

4. O'Grady, N.P.; Alexander, M.; Dellinger, E.P.; Gerberding, J.L.; Heard, S.O.; Maki, D.G.; Masur, H.; McCormick, R.D.; Mermel, L.A.; Pearson, M.L.; Raad, I.I.; Randolph, A.; Weinstein, R.A. (2002). Guidelines for the prevention of intravascular catheter-related infections. Centers for Disease Control and Prevention. MMWR Recomm. Rep., 9 (51), 1-29.

5. CDC. (1999). National Nosocomial Infections Surveillance (NNIS) System report, data summary from January 1990 - May 1999, issued June 1999. Am. J. Infect. Control, 27 (6), 520-532.

6. Chen, Y.C.; Chang, S.C.; Sun, C.C.; Yang, L.S.; Hsieh, W.C.; Luh, K.T. (1997). Secular trends in the epidemiology of nosocomial fungal infections at a teaching hospital in Taiwan, 1981 to 1993. Infect. Control Hosp. Epidemiol., 18 (5), 369-375.

7. Chien, L.Y.; Macnab, Y.; Aziz, K.; Andrews, W.; McMillan, D.D.; Lee, S.K.; Canadian Neonatal Network. (2002). Variations in central venous catheter-related infection risks among Canadian neonatal intensive care units. Pediatr. Infect. Dis. J., 21 (6), 505-511.

8. Collignon, P.J.; Soni, N.; Pearson, I.Y.; Woods, P.; Munro, R.; Sorrel, T.C. (1986). Is semiquantitative culture of central vein catheter tips useful in the diagnosis of catheter-associated bacteremia? J. Clin. Microbiol., 24 (4), 532-535.

9. Cunha, M.L.R.S.; Lopes, C.A.M.; Rugolo, L.M.S.S.; Chalita, L.V.A.S. (2002). Significância clínica de estafilococos coagulase-negativa isolados de recém-nascidos. J. Pediatr. (Rio J)., 78 (4), 279-288.

10. Cunha, M.L.R.S.; Sinzato, Y.K.; Silveira L.V. (2004). Comparison of methods for the identification of coagulase-negative staphylococci. Mem. Inst. Oswaldo Cruz, 99 (8), 855-860.

11. D'Angio, C.T.; McGowan, K.L.; Baumgart, S.; St Geme, J.; Harris, M.C. (1989). Surface colonization with coagulase-negative staphylococci in premature neonates. J. Pediatr., 114 (6), 10291034.

12. Donelli, G.; De Paoli, P.; Fadda, G.; Marone, P.; Nicoletti, G.; Varaldo, P.E. (2001). A multicenter study on central venous catheter-associated infections in Italy. J. Chemother, 13 (1), 251-262. 
13. Fernandes, A.C.S.; Sousa Junior, F.C.; Oliveira, S.M.; Calich, L.; Milan, E.P. (2007). Prevalence of Candida species in umbilical catheters implanted in newborns in Natal, Brazil. Braz. J. Microbiol., 38 (1), 104-107

14. Finelli, L.; Livengood, JR.; Saiman, L. (1994). Surveillance of pharyngeal colonization: detection and control of serious bacterial illness in low birth weight infants. Pediatr. Infect. Dis. J., 13 (10), 854-859.

15. Gastmeier, P.; Schumacher, M.; Daschner, F.; Ruden, H. (1997). An analysis of two prevalence surveys of nosocomial infection in German intensive care units. J. Hosp. Infect., 35 (2), 97-105.

16. Goldman, D.A.; Pier, G.B. (1993). Pathogenesis of infections related to intravascular catheterization. Clin. Microbiol. Rev., 6 (3), 176-192.

17. Guyer, B.; Strobino, D.M.; Ventura, S.J.; Singh, G.K. (1995). Annual summary of vital statistics. Pediatrics, 96 (6), 1029-1039.

18. Hampton, A.A.; Sheretz, R.J. (1988). Vascular-access infections in hospitalized patients. Surg. Clin. North Am., 68 (1), 57-71.

19. Hudome, S.M.; Fisher, M.C. (2001). Nosocomial infections in the neonatal intensive care unit. Curr. Opin. Infect. Dis., 14 (3), 303-307.

20. Isaacs, D.; Australasian Study Group For Neonatal Infections. (2003). A ten year, multicenter study of coagulase negative staphylococcal infection in australasian neonatal units. Arch. Dis. Child. Fetal Neonatal Ed., 88 (2), F89-F93.

21. Kloos, W.E.; Bannerman, T.L. (1995). Staphylococcus and Micrococcus. In: Murray, P.R., Baron, E.J.; Pfaller, M.A.; Tenover, F.C.; Yolken, R.H. (eds). Man. Clin. Microbiol. $6^{\text {th }}$ ed. American Society Microbiology Press, Washington D.C. p.282-298.

22. Kloos, W.E.; Schleifer, K.H. (1975). Simplified scheme for routine identification of human Staphylococcus species. J. Clin. Microbiol., 1 (1), 82-88.

23. Koneman, E.W.; Allen, S.D.; Janda, W.M.; Schreckenberger, P.C.; Winn, Jr. W.C. (1997). Color Atlas Textbook Diagn. Microbiol. $5^{\text {th }}$ ed. JB Lippincott, Philadelphia, USA, 1488p.

24. Maki, D.G.; Weise, C.E.; Sarafin, H.W. (1977). A semiquantitative culture method for identifying intravenous-catheter-related infection. N. Engl. J. Med., 296 (23), 1305-1309.
25. Mehr, S.S.; Sadowsky, J.L.; Doyle, L.W.; Carr, J. (2002). Sepsis in neonatal care in late 1990s. J. Paediatr. Child. Health., 38 (3), 246-251.

26. Nagata, E.; Brito, A.S.J.; Matsuo, T. (2002). Nosocomial infections in a neonatal intensive care unit: incidence and risk factors. $A m . J$. Infect. Control., 30 (1), 26-31.

27. National Committee for Clinical Laboratory Standards. (2002). Performance standards for antimicrobial disk susceptibility tests. Villanova, PA, USA. NCCLS document M100-S12.

28. Randolph, A.G.; Brun-Bruinson, C.; Goldman, D. (2005). Identification of central venous catheter related infections in infants and children. Pediatr. Crit. Care Med., 6 (3), S19-S24.

29. Rao, S.; Joseph, M.P.; Lavi, R.; Macaden, R. (2005). Infections related to vascular catheters in a pediatric intensive care unit. Indian Pediatr., 42 (7), 667-725.

30. Safdar, N.; Fine, J.P.; Maki, D.G. (2005). Meta-analysis: methods for diagnosing intravascular device-related bloodstream infection. Ann. Intern. Med., 142 (6), 451-466.

31. Stratton, C.W. (1998). Catheter-associated infections: a necessary evil. Antimicrobics and Infect. Dis. Newslett., 17 (7), 49-54.

32. Stoll, B.J.; Gordon, T.; Korones, S.B.; Shankaran, S.; Tyson, J.E.; Bauer, C.R.; Fanaroff, A.A.; Lemons J.A.; Donovan, E.F.; Oh, W.; Stevenson, D.K.; Ehrenkranz R.A.; Papile, L.; Verter, J.; Wright, L.L. (1996). Late-onset sepsis in very low birth weight neonates: a report from the National Institute of Child Health and Human Development Neonatal Research Network. J. Pediatr., 129 (1), 63-71.

33. Urrea, M.; Iriondo, M.; Thio, M.; Krauel, X.; Serra, M.; LaTorre, C.; Jiménez R. (2003). A prospective incidence study of nosocomial infections in a neonatal care unit. Am. J. Infect. Control., 31 (8), 505-507.

34. Vermont, C.L.; Hartwig, N.G.; Fleer, A.; de Man, P.; Verbrugh, H.; van den Anker, J.; de Groot, R.; van Belkum, A. (1998). Persistence of clones of coagulase-negative staphylococci among premature neonates in neonatal intensive care units: two-center study of bacterial genotyping and patient risk factors. J. Clin. Microbiol., 36 (9), 2485-2490.

35. Wright, P.F.; Wright, P.F. (1998). Infectious diseases in early life in industrialized countries. Vaccine, 16 (14/15), 1355-1359. 